\title{
ECONOMICS
}

\section{Emission Reduction and Foreign Direct Investment Nexus in China}

\author{
by \\ Yuan Xu \\ Nanjing University of Economics and Finance \\ Yanrui Wu \\ The University of Western Australia \\ and \\ Yongli Shi \\ Nanjing University of Economics and Finance
}




\title{
Emission Reduction and Foreign Direct Investment Nexus in China
}

\author{
Yuan $\mathrm{Xu}^{1}$, Yanrui $\mathrm{Wu}^{2 *}$, Yongli $\mathrm{Shi}^{1}$ \\ ${ }^{1}$ Nanjing University of Economics and Finance \\ ${ }^{2}$ University of Western Australia
}

\begin{abstract}
This paper employs a difference-in-difference-in-difference approach to examine the emission reduction and foreign direct investment nexus in China. It combines a firm-level dataset with emission reduction target statistics at city-level. The findings indicate that stringent environmental regulation is associated with the fall of the output of foreign firms in general and the shrinking of pollution-intensive industries in cities with heavy emission reduction pressure in particular. It is also shown that the location choice of foreign investment changes as emission reduction targets at city-level vary. Finally it is found that environmental regulation helps improve the structure of foreign direct investment and hence contributes to industrial upgrading in the economy.
\end{abstract}

Keywords: Emission reduction; foreign direct investment; environmental regulation; DDD method; China

\footnotetext{
*Corresponding author: yanrui.wu@uwa.edu.au. The authors thank the editors, two anonymous referees and participants of HK Conference (on-line) on Recent Advances in International Trade, Finance, Business and Regional Cooperation (30 Nov 2020) for helpful comments.
} 


\section{Introduction}

Foreign direct investment (FDI) has played an essential role in China's economy, for example, by stimulating trade and promoting productivity improvement through technology transfer (Blalock \& Gertler, 2008; Dean et al., 2009; Gunby et al., 2017; Zhang, 2017). However, in recent years, China's comparative advantage in attracting FDI is diminishing and FDI is no longer an important contributor to the country's trade surplus and industrial output (Ken, 2013; Salike, 2016). In particular, several trends have emerged. First, some multinationals in labor-intensive industries are relocating to other countries due to wage and other cost pressures. Second, the inflow of manufacturing FDI has declined since 2013, but FDI in services has maintained a high growth rate. In fact, the service sector has replaced the manufacturing industry with the largest share of FDI. Third, although the eastern region continues to absorb the overwhelming share of foreign investment, manufacturing FDI in the central and western regions increased significantly. From 2003 to 2017, the share of manufacturing FDI of the central and western regions increased from $9 \%$ to $53 \%$. Finally, due to the increasing competitiveness of domestic manufacturing firms, foreign firms (or FDI firms) are shifting to invest in high-tech and new industries.

Many economic and policy factors are responsible for the above-mentioned changes. Among them, environmental regulatory reform is an important one. In 2006, China's central government specifically targeted pollution reduction through the implementation of the 11th Five-Year Plan (2006-2010) for the first time. Subsequently, in 2007, China's Ministry of Environmental Protection and National Development and Reform Committee specified the reduction targets at the provincial level (MEP, 2006). These targets were mandatory. If the emission reduction targets are not fulfilled, local officials' political careers are affected negatively. These initiatives incentivize local officials to make efforts to meet emission reduction targets (Kahn et al., 2015).

There is a large body of literature addressing the effect of environmental regulation on FDI flows (Taylor, 2005; Cole et al., 2011; Dijkstra et al., 2011; Tang, 2015; Cole et al., 2017). The pollution haven hypothesis states that stringent environmental 
regulations in industrial countries lead to the relocation of dirty industries away from developed countries toward developing economies (Taylor, 2005). However, many empirical studies fail to provide convincing evidence to support the pollution haven hypothesis (Eskeland \& Harrison, 2003; Dean et al., 2009; Zeng \& Eastin, 2012; Chung, 2014; Cai et al. 2016; Huang et al., 2017; Dechezleprêtre \& Sato, 2017). In the context of China, Wu et al. (2017) and Chen et al. (2018) show that, with the increasingly stringent environmental regulation, pollution-intensive firms are relocating to the central and western regions where there is less pressure for emission reduction. Although the impact of China's changing environmental governance model has attracted a lot of attention, FDI is under-documented in the literature. In 2005, the output share of FDI firms is $33 \%$ in COD pollution-intensive industries and $23 \%$ in $\mathrm{SO}_{2}$ pollution-intensive industries ${ }^{1}$. Thus it is important to understand the impact of emission reduction policy on FDI firms.

This study extends the literature in several ways. First, the existing literature mainly focuses on examining the pollution heaven hypothesis in regards to FDI in China (Dean el at., 2009; Huang et al., 2017). This study presents a comprehensive assessment of the impact of emission reduction targeting policy introduced through China's Five-Year Plan (2006-2010) on FDI. It aims to explore the impact of emission reduction targeting on the performance of existing FDI firms, the location choice of new entrants and the industrial structure of FDI inflows. Second, one of the challenges in empirical analysis is to deal with measurement errors due to endogenous environmental regulation variables and unobservable factors (Jeppesen et al., 2002; Cole \& Fredriksson, 2009; Levinson, 2010; Millimet \& Roy, 2016). To overcome this problem, we focus on emission reduction targeting in China's "Five-Year Plan" which is a pre-regulatory policy and hence an exogenous change, and adopt a difference-in-

\footnotetext{
${ }^{1}$ The COD pollution intensive sectors in manufacturing include beverages, textile, paper and paper products, raw chemical materials and chemical products, medicines, chemical fibers, rubber and plastics. The SO2 pollution intensive sectors in manufacturing include petroleum, raw chemical materials and chemical products, medicines, chemical fibers, rubber, plastics, non-metallic mineral products, smelting and pressing of ferrous metals, and smelting and pressing of non-ferrous metals.
} 
difference-in-difference (DDD) method (Berrone et al. 2013; Fang et al., 2019). Third, Cai et al., (2016) may be the closest work to this study. These authors considered the effect of the so-called two control zones (TZC) policy on the scale of FDI inflows only. According to this policy, Chinese cities are broadly divided into two groups. Therefore, the work by Cai et al. (2016) is very broad and fails to reveal detailed insights at the city and industry level which this paper can provide.

The remainder of this paper is organized as follows. Section 2 presents the research hypotheses. Data, modelling issues and empirical results are discussed in Section 3. Section 4 provides further analyses. Section 5 concludes the paper.

\section{Research hypotheses}

\subsection{Emission reduction targeting in China}

Pollution control is a typical public good which is associated with the problems such as free-riding and tragedy of the commons (Arrow et al., 1996). National governments generally resort to command-and-control environmental regulations and financial instrument (such as carbon emission trading and pollution discharge rights) to make up the market failure and reduce pollution (Marshall, 1998; Fare et al., 2013). In China, although the central government maintains its authority over environmental planning, most fundamental enforcement decision making and responsibilities are allocated to local and regional governments (Yang, 2017).

As a result, this top-down regulatory system primarily following a command-andcontrol approach fails to curb China's increasingly severe environmental degradation. China's central government is aware of the situation and concerned about the sustainable development of the country's economy. In 2006, it launched and implemented a quantitative targeting environmental policy ("National Plan for Total Emissions Control of Major Pollutants"). The goal was to reduce the total emission of major pollutants $\left(\mathrm{COD}\right.$ and $\mathrm{SO}_{2}$ ) at the national level by $10 \%$ (relative to emissions in 2005) during the 11th Five-Year Plan Period (2006-2010). To ensure the success of this policy, the central government adopted the target responsibility system of energy conservation and pollution reduction, which is a top-down policy implementation 
mechanism (Qi, 2013). First the central government designated pollution reduction targets for provincial governments, and then the provincial governments set the targets for municipal governments. Second, the central government signed the target responsibility contracts with the provincial governments, and the provincial governments normally signed the target responsibility contracts with lower level governments. This policy was effective and the stated pollution reduction goals were fulfilled ahead of schedule. It eventually led to a reduction of total $\mathrm{SO}_{2}$ emission by $14.3 \%$ and COD emissions by $12.4 \%$ at the end of 2010 .

\subsection{Research hypotheses}

Under the pressure of emission reduction targeting, FDI firms' investment decisions are influenced by increasing compliance costs. In general, the firms have to internalize these extra costs such as the purchase of environmental pollution control equipment in response to higher standards of environmental regulations. However, as adopting new environment-friendly production equipment requires learning time, the marginal cost of production increases and firm profitability may be affected (Kemp \& Pontoglio, 2011). Furthermore, tighter environmental regulations may increase the uncertainty faced by firms and delay their investment decision. Greenstone (2002) indicated environmental regulation could weaken the productivity of US manufacturing and induce output losses. The total output value of pollution-intensive FDI firms in cities under great pressure to reduce emission may decrease more than that of firms in cities with relatively lax regulation stringency. Therefore, we put forward the following research hypothesis:

Hypothesis H1: Emission reduction targeting has a negative impact on the output of FDI firms, other things being equal.

In general, the emission reduction policy has led to a continuous tightening of environmental regulations which tends to increase the production costs of pollutionintensive industries and have a "crowding effect" on high-level polluting firms (Kemp \& Pontoglio, 2011). The existing studies show that with strict environmental regulations firms with lower cost of pollution control enjoy green comparative 
advantage, while those with high cost of pollution control may be forced out of the market because they are unable to absorb the cost of relocating or upgrading their equipment to reduce emissions. As a result, environmental regulations can be regarded as the new driving force for industrial structural adjustment (Zhou et al., 2017). Furthermore, for the cleaner production industries, the stricter the environmental regulations are, the greater the profits in these sectors. As a result the profit gap between different industries widens and production factors flow to more profitable enterprises. These changes promote the upgrading of the industrial structure (Wang \& Shen, 2016). In addition, the indirect effect of environmental regulations on industrial upgrading can be explained by the Porter hypothesis. Although environmental regulation will increase the additional cost in the early and short term, it will become an incentive for R\&D input and innovation in the long run. Therefore, with strict environmental regulations, both polluting and clean firms will increase the intensity of R\&D investment to absorb environmental protection costs through technological advancement, which will is the source of the incentive effect and spillover effect of technological innovation, and ultimately drives the adjustment of industrial structure (Domazlicky \& Weber, 2004; Wang et al., 2016). Therefore, we propose the second hypothesis as follows:

Hypothesis H2: Emission reduction targeting contributes to the overall industrial upgrading as it discourages pollution-intensive FDI and promotes hi-tech FDI.

It is argued that stringent environmental regulations may lead to the relocation of dirty industries away from developed countries toward developing economies (Keller \& Levinson, 2002; List et al., 2004; Cai et al., 2016; Millimet \& Roy, 2016). This phenomenon is known as the pollution haven hypothesis in the literature. Empirical studies generally focus on cross-country comparison. In China, there is huge disparity in factor endowment and economic development cross the regions (Dean et al., 2009). In addition, the current system of governance entrusts local governments with the right of environmental supervision. As a result, the cost of pollutant discharge faced by firms in different regions varies substantially. This variation leads to the phenomenon of pollution transfer between regions in China (Duviver \& Xiong, 2013; Cai et al., 2016; 
Wu et al., 2017). Lin \& Sun (2016) argued that the reforms in 2006 not only brought more stringent environment regulations throughout the country, but also led to greater regional variation in enforcement stringency. Pollution-intensive FDI firms tend to move into cities with less pressure to reduce emission, while technology-intensive FDI firms can still survive in cities with higher emission reduction targets. According to the median value of the emission reduction variable, the sample cities can be divided into two groups, namely cities with low emission pressure (below the median) and cities with high emission pressure (above the median). A preliminary analysis shows that during 1998-2005 or before the implementation of the 11th Five-Year Plan"16.1\% of newly established $\mathrm{SO}_{2}$ pollution-intensive FDI firms were located in cities with low emission pressures (usually cities with relatively backward economies in the region) but this proportion increased to $21.4 \%$ during 2006-2013. Similarly, for newly established COD pollution-intensive FDI firms, $16.7 \%$ were allocated in cities with low emission pressures during1998-2005, but this share increased to $19.8 \%$ during 20062013. These observations lead to our third hypothesis:

Hypothesis H3: Emission reduction targeting leads to more inflow of pollution intensive FDI in cities with low emission reduction targets.

\section{The estimation strategy and results}

\subsection{Estimation strategy}

The time and spatial variations of adopting the emission reduction targets in China provide an opportunity for implementing a difference-in-difference (DID) strategy. We can compare the performance of FDI firms in cities with great pressure for emission reduction before and after 2006 with that in cities with low pressure. However, some time-varying urban characteristics may be correlated with the outcome variable and the regressors and hence the DID estimates are biased (Shi \& Xu, 2018). Moreover, given a large set of city-specific variables affect firm performance, it is difficult to include all of them in the DID model. Finally, to set the pollution reduction targets, the central and local governments particularly focus on high-polluting industries. In view of the DID 
problems and policy making practice in China, a difference-in-difference-in-difference (DDD) method is chosen in this paper. This technique can overcome the endogeneity problem due to omitted time varying city-specific characteristics and hence provide more robust estimates ${ }^{2}$. It provides more robust estimates than the use of dummy or instrumental variables (IVs) as the latter may lead to small degree of freedom if too many dummies or IVs are involved or biases due to the presence of multiple cofounding trends (Imbens and Wooldridge, 2007). Specifically, three types of variation (emission reduction target, time and emission intensity) are incorporated in a balanced panel data model as follows:

$$
F D I_{i c t}^{f}=\varphi * \operatorname{Tar}_{c} * \text { Post }_{t} * E I_{i}+\mu_{c t}+\delta_{c i}+\gamma_{t i}+\varepsilon_{i c t}
$$

where $F D I_{\text {ict }}^{f}$ represents gross industrial output value (in logarithm) in year $t$ of FDI firm $f$ in industry $i$ and city $c$; $\operatorname{Tar}_{c}$ is the emission reduction target for city $c$; Post $t_{t}$ is a dummy variable which takes the value of 0 for the years of 2000-2005 and 1 for the years of 2006-2013; $E I_{i}$ is the emission intensity for industry $i$ which is measured as the average $\mathrm{SO}_{2}$ or COD emission intensity (pollutant volume over industrial output) across three years $\left(2005,2010\right.$ and 2015); and $\varepsilon_{i c t}$ is an error term with zero mean. The DDD specification in equation (1) makes it possible to include city-year fixed effects $\mu_{c t}$ (to capture factors such as financial markets, open policies, degree of marketization, industrial agglomeration and so on), industry-year effects $\gamma_{t i}$ (such as industrial policies, market access, technological changes and so on), and industry-city fixed effects $\delta_{c i}$. To control for heterogeneity and serial correlations, we calculate the standard error by clustering over city-industry. A significantly negative value of the regression coefficient $\varphi$ indicates that emission reduction targets are negatively associated with the output of FDI firms and thereby verifies Hypothesis H1.

\subsection{Data}

The actual reduction targets of major pollutants at the city level are obtained manually

\footnotetext{
${ }^{2}$ It is noted that the DDD method has been criticized for the lack of exposition of its estimates and their identifying assumptions (Olden \& Moen 2020).
} 
from relevant policy documents or through applications for information disclosure with various provincial and municipal government departments. Emission reduction targets are available for all (but Hainan, Tibet, Qinghai, and Xinjiang) provinces. For some cities which are allowed to increase their emissions, the emission reduction target is assigned a value of 0 . The advantage of using emission reduction targets as an environmental regulatory variable is that these targets are unlikely to be affected by polluting firms and hence are exogenous in the model.

FDI data are drawn from the Annual Survey of Industrial Firms conducted by the National Bureau of Statistics of China (NBS) for the period of 2003-2013. The survey covered all state-owned firms and those non-state-owned firms with the value of annual sales of at least five million Renminbi $(R M B)$. This is the most comprehensive firmlevel dataset and widely used by researchers. We clean the data by following the standard procedures in the literature (such as Brandt et al., 2012). We identify FDI firms according to the type of business registration. Pollutant emission data including industrial $\mathrm{SO}_{2}$ and $\mathrm{COD}$ for 230 cities are sourced from the Annual Statistical Yearbook of Cities. The emission intensity of pollutants in different industries is the average value in 2005, 2010 and 2015 which is drawn from the China Environmental Statistics Yearbook. The R\&D intensity data of different industries are from Data Bulletin of the Second National R\&D Resource Inventory collected by NBS (The summary statistics of the main variables are presented in the appendix).

\subsection{Empirical results}

\subsubsection{Testing Hypothesis H1}

Table 1 reports the estimation results based on equation (1) which investigates the differences before and after the introduction of $\mathrm{SO}_{2}$ emission reduction targets in 2006 . The coefficient value in column (1) shows that when the emission reduction target is one standard deviation higher than the mean value, the output value of firms in polluting industries with $\mathrm{SO}_{2}$ emission intensity being $10 \%$ higher than the mean value will decrease by $1.83 \%{ }^{3}$. Similarly, the value of the coefficient in column (2) shows that

\footnotetext{
${ }^{3}$ The marginal effect is calculated by using this formula: $\Delta=\hat{\varphi} * \ln \left(\operatorname{Tar}_{\text {mean }}+\operatorname{Tar}_{s d}\right) *$ $\ln \left(E I_{\text {mean }} *(1+10 \%)\right)-\hat{\varphi} * \ln \left(\right.$ Tar $\left._{\text {mean }}\right) * \ln \left(E I_{\text {mean }}\right)$.
} 
when the emission reduction target is one standard deviation higher than the mean value, the output value of firms in polluting industries with COD emission intensity being $10 \%$ higher than the mean value will decrease by $2.02 \%$. The results suggest that emission reduction targets have a significant negative impact on the output of FDI firms at citylevel, and have a greater impact on pollution-intensive industries in cities with high emission reduction pressure. Thus hypothesis $\mathrm{H} 1$ is confirmed.

Table 1 The effect of environmental regulations and the output of FDI firms

\begin{tabular}{lcccc}
\hline & $(1)$ & $(2)$ & $(3)$ & $(4)$ \\
\hline & OLS & OLS & 2SLS & 2SLS \\
\hline SO2 & COD & SO2 & COD \\
\hline Tar*Post*EI & $-0.00628^{* *}$ & $-0.00776^{* *}$ & $-0.0449^{* *}$ & $-0.0167^{* *}$ \\
& $(0.00309)$ & $(0.00368)$ & $(0.01570)$ & $(0.00763)$ \\
city-industry FEs & YES & YES & YES & YES \\
city-year FEs & YES & YES & YES & YES \\
Industry-year FEs & YES & YES & YES & YES \\
Observations & 517,668 & 517,668 & 517,668 & 517,668 \\
R-squared & 0.252 & 0.252 & & \\
\hline
\end{tabular}

\begin{tabular}{lcc}
\hline & \multicolumn{2}{c}{ The first stage } \\
\hline $\operatorname{lnVC}$ & $0.572^{* * *}$ & $1.232^{* * *}$ \\
& $(0.0146)$ & $(0.0112)$ \\
F-test & $1533^{* * *}$ & $12070^{* * *}$ \\
C-D Wald F stats & 5618 & 42000 \\
\hline
\end{tabular}

Note: $* * *, * *$ and $*$ represent significance at the level of $1 \%, 5 \%$ and $10 \%$, respectively. Standard error is in brackets. FEs: fixed effects.

Although the adoption of pollution reduction targets as the proxy variable of environmental regulation can overcome the endogenous problem as much as possible in previous studies. The actual efforts of local officials on environmental governance may not be fully captured by the emission reduction targets issued by upper level governments. In fact, according to the actual situation of economic development, provincial leaders may offer lower reduction targets for their favorite city leaders (Jia et al., 2015; Chen et al., 2017). In order to address the issue that biased emission reduction targets may incorrectly measure actual regulatory stringency, we follow the literature to use the ventilation coefficients at city level as the IV for pollution reduction targets (Chen et al., 2018; Deng et al., 2021). In general, for the same amount of pollutants being discharged, the cities with low ventilation coefficients tend to adopt 
strict environmental regulation. The ventilation coefficient is equal to the wind speed times the height of the boundary layer. ${ }^{4}$ In this paper, the two-stage least square (2SLS) method is used to re-estimate equation (1). According to columns (3) and (4) in Table 1 , the $\mathrm{F}$ values of the first-stage regression are all greater than 10 and significant at the level of $1 \%$, indicating no problem of weak instrumental variable $(\ln \mathrm{VC})$. The secondstage estimates show that, the weak identification test statistics and the insufficient identification test statistics both reject the hypothesis that the IV variable $(\operatorname{lnVC})$ is irrelevant to and weakly correlated with emission reduction targets. The results in columns (3) and (4) of Table 1 are consistent with those in columns (1) and (2) and illustrate that emission reduction targeting has a significant hindering effect on the FDI firms. Therefore hypothesis $\mathrm{H} 1$ is still valid.

\subsubsection{Testing hypothesis $\mathbf{H} 2$}

To test hypothesis $\mathrm{H} 2$, in the empirical model, we replace emission intensity variable with the R\&D intensity at the industry level and hence consider the following model:

$$
F D I_{i c t}^{f}=\rho_{2} * \operatorname{Tar}_{c} * \text { Post }_{t} * R \& D_{i}+\mu_{c t}+\delta_{c i}+\gamma_{t i}+\varepsilon_{i c t}
$$

where $R \& D_{i}$ is the R\&D intensity of industry $i$ and other variables have the same definition as those in equation (1). It is expected that the estimated value of $\rho_{2}$ is significantly positive, indicating that emission reduction targeting may make cities with stricter environmental regulations to attract more high-tech-intensive FDI, and ultimately helps achieve the goal of industrial upgrading in general and optimizing FDI structure in particular.

First, we estimate equation (2) by using the full sample. The results in Table 2 are consistent with our expectation. Stringent environmental regulations have a positive impact on FDI firms in R\&D intensive industries. When the emission reduction target is a standard deviation higher than the average, the output of FDI firms in industries with R\&D intensity being $10 \%$ higher than the average would increase by $1.2 \%-12 \%$. Thus R\&D intensive FDI firms in China are less sensitive to environmental regulation

\footnotetext{
${ }^{4}$ The ERA-interim database of the European Center for Medium-Range Weather Forecasts (ECMWF: https://www.ecmwf.int/en/forecasts/datasets/reanalysis-datasets/era-interim) provides global wind speed and boundary layer height data.
} 
given their relatively cleaner production technology.

Table 2 Emission reduction targeting and industrial upgrading

\begin{tabular}{lcccc}
\hline & $(5)$ & $(6)$ & $(7)$ & $(8)$ \\
\hline & OLS & OLS & 2SLS & 2SLS \\
\hline Tar*Post*RD & SO2 & COD & SO2 & COD \\
& $0.0226^{* * *}$ & $0.0240^{* * *}$ & $0.0137^{* * *}$ & $0.0558^{* * *}$ \\
city-industry fixed & $(0.00716)$ & $(0.00726)$ & $(0.0377)$ & $(0.0153)$ \\
city-year fixed & YES & YES & YES & YES \\
Industry-year fixed & YES & YES & YES & YES \\
Observations & 517,668 & YES & YES & YES \\
R-squared & 0.252 & 0.252 & 517,668 & 517,668 \\
\hline & & & & The first stage \\
\hline lnVC & & & $0.522^{* * *}$ & $1.2795^{* * *}$ \\
& & & $(0.0124)$ & $(0.00911)$ \\
F-test & & & $1771^{* * *}$ & $19724 * * *$ \\
C-D Wald F statistic & & & 4846 & 42812 \\
\hline
\end{tabular}

Note: $* * *, * *$ and $*$ represent significance at the level of $1 \%, 5 \%$ and $10 \%$, respectively.

Standard error is in brackets.

Second, we estimate equation (2) by using the subsample of newly established FDI firms. The results are shown in Table 3 and the estimated value of the coefficients of the interaction term is generally positive. Therefore we may conclude that stringent environmental regulations may contribute to the entrance of new R\&D-intensive FDI firms. Cities with greater pressure to reduce emissions may attract more R\& D-intensive FDI firms. Thus the improvement of environmental regulation may help attract highquality FDI and eventually leads to the optimization of the industrial structure in general, thereby confirming Hypothesis H2.

\subsubsection{Testing hypothesis $\mathbf{H 3}$}

To test hypothesis H3, we consider the new firms in each industry-city-year from 20002013 and then use the amount of foreign capital $\left(N F D I_{i c t}^{f}\right)$ of these firms as the explanatory variable in equation (1). Ideally, to examine the effect of emission reduction targeting on location choice, one should consider migrating firms. This however is impossible given the data available. Instead we explore how new firms respond to regulatory changes. The model can be expressed as follows:

$$
N F D I_{i c t}^{f}=\rho_{1} * \operatorname{Tar}_{c} * \text { Post }_{t} * E I_{i}+\mu_{c t}+\delta_{c i}+\gamma_{t i}+\varepsilon_{i c t}
$$


where $N F D I_{i c t}^{f}$ is the amount of foreign capital of a newly established FDI firm $f$ of industry $i$ in city $c$ in year $t$ and other variables are the same as defined in equations (1) and (2). It is expected that the regression coefficient value $\rho_{1}$ is significantly negative, indicating that emission reduction targeting has a significant impact on the location choice of FDI, and that pollution-intensive FDI firms tend to flow into cities with less pressure for emission reduction.

Table 3 Emission reduction and FDI industrial structure: New firms

\begin{tabular}{lcccc}
\hline & $(9)$ & $(10)$ & $(11)$ & $(12)$ \\
\hline & OLS & OLS & 2SLS & 2SLS \\
\hline Tar*Post*RD & SO2 & COD & SO2 & COD \\
& $0.0315^{* *}$ & 0.0275 & $0.0588^{*}$ & 0.0545 \\
city-industry fixed & $(0.0135)$ & $(0.0197)$ & $(0.0306)$ & $(0.0400)$ \\
city-year fixed & YES & YES & YES & YES \\
Industry-year fixed & YES & YES & YES & YES \\
Observations & 96,228 & YES & YES & YES \\
R-squared & 0.271 & 0.271 & 96,228 & 96,228 \\
\hline & & & & \\
\hline lnVC & & & $1.285^{* * *}$ & $1.385^{* * *}$ \\
& & & $(0.1559)$ & $(0.0211)$ \\
F-test & & & 67.94 & 4311.69 \\
C-D Wald F statistic & & & 6063.31 & 8065.17
\end{tabular}

Note: $* * *, * *$ and $*$ represent significance at the level of $1 \%, 5 \%$ and $10 \%$, respectively.

Standard error is in brackets.

The estimation results in Table 4 show that the coefficients of the interaction term in models (13) and (15) are significantly negative when $\mathrm{SO}_{2}$ emission reduction targets are considered, indicating that cities with a low emission reduction target attract more pollution-intensive FDI inflows than those with a high emission reduction target. In addition, the coefficients of the interaction term are not significant when COD emission reduction targets are considered. This discrepancy may be partly caused by the fact that water pollution-intensive industries may not be very footloose and are consequently less willing or likely to move for environmental cost saving which is small relative to the large operation cost. In general, as far as $\mathrm{SO} 2$ is concerned, hypothesis $\mathrm{H} 3$ is confirmed. 
Table 4 Impact of environmental regulations on entry of FDI firms

\begin{tabular}{lcccc}
\hline & $(13)$ & $(14)$ & $(15)$ & $(16)$ \\
\hline & OLS & OLS & 2SLS & 2SLS \\
\hline SO2 & COD & SO2 & COD \\
\hline city-industry fixed & $-0.0116^{*}$ & -0.00821 & $-0.0364^{*}$ & -0.0185 \\
city-year fixed & YES & YES & YES & YES \\
Industry-year fixed & YES & YES & YES & YES \\
Observations & 96,228 & YES & YES & YES \\
R-squared & 0.271 & 0.228 & 96,228 & 96,228 \\
& & & & \\
\hline GER & & & $1.386^{* * *}$ & $1.328^{* * *}$ \\
& & & $(0.0314)$ & $(0.0247)$ \\
F-test & & & 1955.17 & 2889.53 \\
C-D Wald F statistic & & & 6329.94 & 8159.09 \\
\hline
\end{tabular}

Note: $* * * * *$ and $*$ represent significance at the level of $1 \%, 5 \%$ and $10 \%$, respectively. Standard error is in brackets.

\section{Robustness checks}

In this section further analyses are conducted to check the robustness of the estimation results in the preceding section. First, we allow for emission reduction variation over time (Section 4.1). Second, we exclude interruptions due to the 2008 Beijing Olympic Games and global financial crisis (Section 4.2). Third, we consider the effects of leads and lags of environmental regulatory changes (Section 4.3). Fourth, regional differences cannot be ignored in a vast country like China. We will examine the difference between the east coastal region with the interior (central and western China) (Section 4.4). Finally, we distinguish firms with capital of Hong Kong, Macao and Taiwan origin from those originated from other offshore economies (Section 4.5).

\subsection{Emission reduction variation over time}

It can be observed that emission reduction targets are not necessarily implemented concurrently across all cities. Some cities may not actively control pollution in the first half of the Five Year Plan (FYP) period, and instead take action in the second half of the period. In contrast, other cities may reach their emission reduction targets in the first three years and have no pressure for emission reduction in the next two years. Therefore, it is necessary to accommodate these variations in our empirical exercises. For this 
purpose, we define the emission reduction target in the first year of the FYP period as the total FYP reduction target divided by 5 . The emission reduction target in the second year of the FYP period is measured as the difference (between the FYP target and the realized reduction in the first year) divided by 4 . The same computation applies to the emission reduction targets in the third, fourth and final year. If the FYP target is reached ahead of time, the emission reduction targets for the remaining years are assigned to be zero. Due to the lack of COD emission data at city level, we only consider $\mathrm{SO}_{2}$ emission reduction targets annually. The results are shown in column (17) of Table 5. The estimated coefficients have the correct sign and magnitude and are significant at the $10 \%$ level or below. Thus these results are consistent with those presented in the preceding section and support the three hypotheses.

\subsection{Interruption events}

In order to keep the promise of a "blue sky" for the 2008 Beijing Olympic Games, the Chinese government adopted a series of mandatory measures targeting high polluting industrial firms around Beijing during 2007-2008. According to the study by He et al. (2016), the affected areas include Beijing, Hebei, Tianjin, Shanxi, Inner Mongolia and Liaoning. To eliminate the impact of this event on the estimation results, cities in the relevant regions in 2007-2008 are excluded from the sample. The estimation results are shown in columns (18) and (19) of Table 5. In addition, the global financial crisis in 2008 had a huge impact on the world economy and cross-border investment activities. To minimize the interruption of this event, 2008 and 2009 samples are excluded from the final sample. The estimation results are presented in columns (20) and (21) of Table 5. These results in columns (18) to (21) are generally consistent with the original findings in terms of the expected sign, magnitude and statistical significance and hence still support the three hypotheses.

\subsection{Impacts of lags and leads}

One potential problem of the DDD estimation is that the environmental effects of emission reduction targeting after 2006 may be partly the consequences of the pollution control efforts of previous governments, while the changes of FDI activities after 2006 
may actually be caused by pre-existing trends. According to the collected provincial emission reduction plans, many local governments assigned emission reduction tasks to local cities in 2007. Furthermore local FDI firms could adopt clean technology or changed their investment behavior in China before 2006. Under these circumstances DDD estimates may be biased. In addition, our regression results reflect the average impact of emission reduction targeting on FDI firms, and cannot capture the difference of the impacts over time. In order to overcome these potential problems, we introduce all the lags and leads into the model as follows:

Table 5 Emission reduction variation over time and interruption events

\begin{tabular}{|c|c|c|c|c|c|}
\hline & $(17)$ & (18) & (19) & $(20)$ & $(21)$ \\
\hline \multirow[t]{2}{*}{ Variables } & Reduction & \multicolumn{2}{|c|}{ Beijing Olympic Games } & \multicolumn{2}{|c|}{ Global financial crisis } \\
\hline & targets (SO2) & $\mathrm{SO} 2$ & COD & $\mathrm{SO} 2$ & COD \\
\hline \multicolumn{6}{|l|}{$\underline{H 1}$} \\
\hline \multirow[t]{2}{*}{ Tar*Post*EI } & $-0.00844^{*}$ & $-0.00662 * *$ & $-0.00808 * *$ & $-0.00671 * *$ & $-0.00829 * *$ \\
\hline & $(0.00480)$ & $(0.00310)$ & $(0.00367)$ & $(0.00314)$ & $(0.00371)$ \\
\hline Observations & 517,668 & 493,180 & 493,180 & 482,593 & 482,593 \\
\hline R-squared & 0.252 & 0.257 & 0.257 & 0.261 & 0.261 \\
\hline \multicolumn{6}{|l|}{$\underline{H 2}$} \\
\hline \multirow[t]{2}{*}{ Tar*Post*RD } & $0.0191 *$ & $0.0228 * *$ & $0.0249 * * *$ & $0.0208 * *$ & $0.0245 * * *$ \\
\hline & $(0.0118)$ & $(0.00940)$ & $(0.00926)$ & $(0.0104)$ & $(0.00956)$ \\
\hline Observations & 517,668 & 493,180 & 493,180 & 482,593 & 482,593 \\
\hline R-squared & 0.241 & 0.246 & 0.246 & 0.250 & 0.250 \\
\hline \multicolumn{6}{|l|}{$\underline{H 3}$} \\
\hline \multirow[t]{2}{*}{ Tar*Post*EI } & $-0.0167 * * *$ & $-0.0116 * * *$ & -0.00798 & $-0.0114 * * *$ & -0.00791 \\
\hline & $(0.00515)$ & $(0.00337)$ & $(0.00573)$ & $(0.00329)$ & $(0.00583)$ \\
\hline Observations & 96,042 & 95,059 & 95,059 & 82,991 & 82,991 \\
\hline R-squared & 0.278 & 0.259 & 0.259 & 0.258 & 0.258 \\
\hline
\end{tabular}

Note: $* * *, * *$ and $*$ represent significance at the level of $1 \%, 5 \%$ and $10 \%$, respectively. Standard error is in brackets. All models include city-industry, city-year and industry-year fixed effects. To save space, the estimates of the intercept terms for each model are not reported.

$$
F D I_{i c t}^{f}=\sum_{j=-5}^{7} \varphi_{j} * \operatorname{Tar}_{c} * \text { Year }_{2006+j} * E I_{i}+\mu_{c t}+\delta_{c i}+\gamma_{t i}+\varepsilon_{i c t}
$$

where Year $_{2006+j}$ represents the year dummy (with 2006 being the reference year in the model) and $\varphi$ the coefficient for each year during 2001-2013. The dependent variable is either output as in equations (1) and (2) or the value of FDI as in equation (3). The explanatory variable $E I_{i}$ is either emission intensity as in equations (1) and (2) or R\&D intensity as in equation (2). The definitions of other variables are the same as 
those in equations (1)-(3).

Figure 1 shows the estimated results of $\varphi$ at $95 \%$ confidence interval. Panels (a), (b) and (c) are based on $\mathrm{SO}_{2}$ emission reduction targets and present the results which are consistent with those in Tables 2-4. Accordingly Panels (d), (e) and (f) present the results based on COD emission reduction targets. It can be seen that the estimated coefficient $\varphi$ varies over time and that a sharp change of pattern since 2006 is observed in general. These changes are consistent with the three hypotheses. It is also noticed that these changes have accelerated since 2009 when environmental performance was introduced as an assessment criterion for the promotion of local officials. The implementation of emission reduction targets in 2006 has a certain lag on the impact of FDI. The reason for the delay may be that, although 2006 was the first year of implementation of the 11th Five-Year Plan, it was not until 2007 that the environmental protection agency quantified the $10 \%$ reduction target and implemented it to local governments through signing a contract of responsibility for the target. At the same time, the implementation of the "Assessment Trial Measures" in 2009 further increased the pressure on local governments', and the impact on FDI firms also deepened.

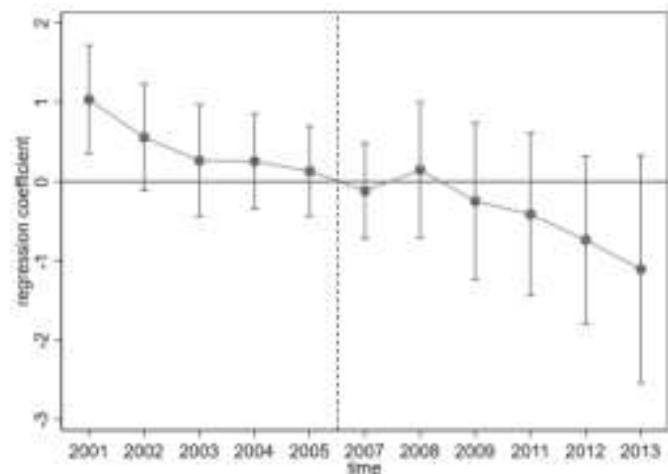

Panel (a)

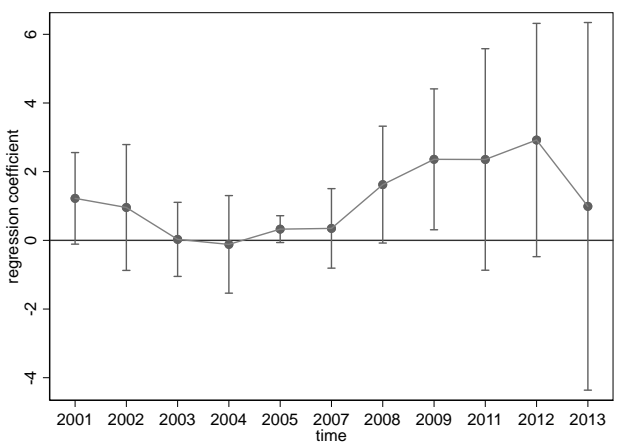

Panel (b)

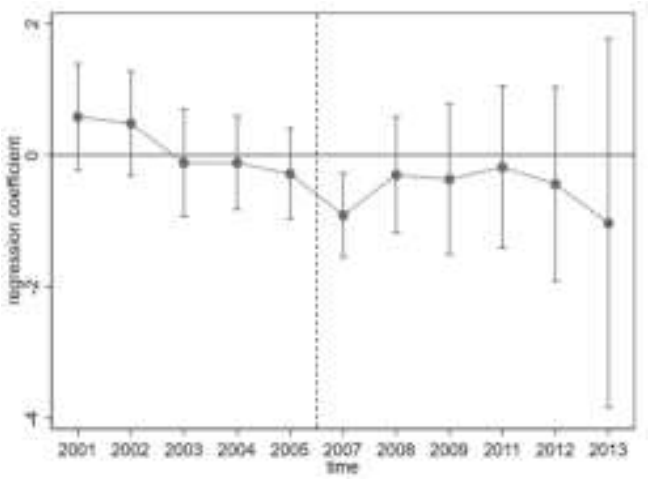

Panel (d)

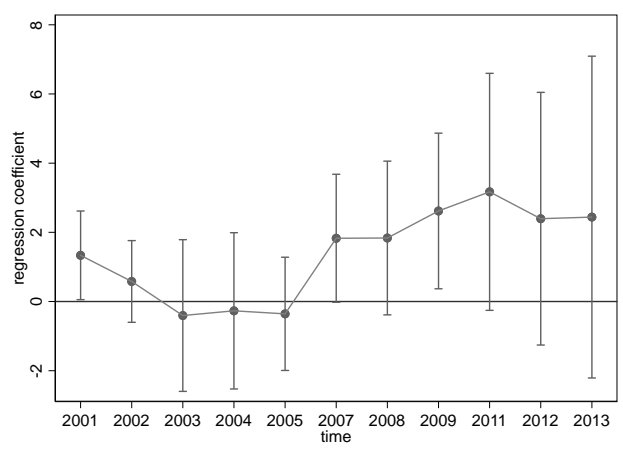

Panel (e) 


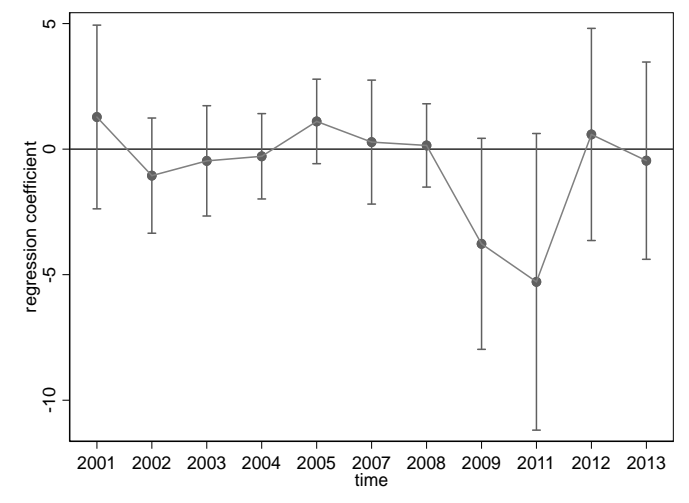

Panel (c)

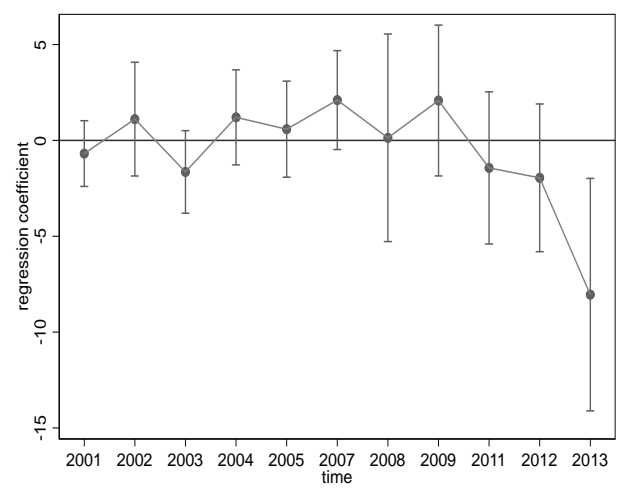

Panel (f)

Figure 1 Dynamic effects of emission reduction targeting

Note: Panels (a), (b) and (c) on the left are based on $\mathrm{SO}_{2}$ emission reduction targets and Panels (d), (e) and (f) on the right are based on COD emission reduction targets. The reference year is 2006 and hence does not appear in the charts.

\subsection{Coastal vs non-coastal regions}

Given the vast size of China, regional differences have to be addressed by the central government. The average emission reduction of $\mathrm{SO}_{2}$ and $\mathrm{COD}$ intensity in eastern or coastal cities is 1.9 and 1.1 times higher than those in central and western or non-coastal cities, respectively. In this section, we test the three hypotheses (H1, H2 and H3) by dividing the sample into coastal and non-coastal groups and repeating the exercises. ${ }^{5}$ The main results are presented in Table 6 .

Several observations are noticed. First, the mandatory emission reduction policy has a significant negative impact on the output of FDI firms in both regions. Thus H1 is supported by both sub-samples. Second, the pressure of compulsory emission reduction has promoted the structural upgrading of FDI firms in the coastal region only (and hence $\mathrm{H} 2$ is confirmed for the coastal region). This finding reflects that the cost pressure faced by FDI firms in the coastal region is relatively greater than that in the noncoastal or central and western regions after the implementation of strict environmental regulation. Finally, the location of newly established FDI firms in the eastern region is affected by environmental regulations, but no such effect is observed

\footnotetext{
5 The coastal region include three municipalities (Beijing, Tianjin and Shanghai) and eight provinces (Hebei, Liaoning, Jiangsu, Zhejiang, Fujian, Shandong, Guangdong and Hainan. The noncoastal region covers central China (eight provinces: Shanxi, Jilin, Heilongjiang, Anhui, Jiangxi, Henan, Hubei and Hunan) and western China (Chongqing municipality and eleven provinces and autonomous districts: Neimenggu, Guangxi, Sichuan, Guizhou, Yunan, Tibet, Shaanxi, Guansu, Qinghai, Ningxia and Xinjiang).
} 
in the noncoastal or central and western regions. Thus H3 is confirmed for the coastal group only. This result shows that the locational adjustment of FDI driven by environmental regulations is not only through the shift from the coastal region to the noncoastal central and western regions, but also in the form of relocation within the coastal region. These changes reflect the disparity between the coastal and non-coastal regions as well as the intra-regional differences in the coastal area. Pollution-intensive firms in the coastal area could move to nearby cities within the same region with relatively loose environmental regulation because these cities usually have advantages over the central and western cities in terms of specific resource endowment, such as infrastructure, industrial base, scientific research and education policies. In addition, relocation within the same province costs much less. Moreover, the difference of emission reduction intensity within the central and western regions is not as great as that within the coastal region. For example, the variance of $\mathrm{SO} 2$ emission reduction targets within the central and western regions is only $57 \%$ of that within the coastal region.

Table 6 Coastal vs non-coastal regions

\begin{tabular}{|c|c|c|c|c|}
\hline & \multicolumn{2}{|c|}{ Coastal region } & \multicolumn{2}{|c|}{ Non-coastal region } \\
\hline & $\mathrm{SO} 2$ & COD & $\mathrm{SO} 2$ & COD \\
\hline \multicolumn{5}{|l|}{$H 1$} \\
\hline \multirow[t]{2}{*}{ Tar*Post*EI } & $-0.00596^{* * * *}$ & $-0.00737^{* * *}$ & $-0.0136^{* *}$ & $-0.0164^{*}$ \\
\hline & $(0.00147)$ & $(0.00194)$ & $(0.00538)$ & $(0.00888)$ \\
\hline Observations & 467,187 & 467,187 & 50,481 & 50,481 \\
\hline R-squared & 0.227 & 0.227 & 0.437 & 0.437 \\
\hline \multicolumn{5}{|l|}{$\mathrm{H} 2$} \\
\hline \multirow[t]{2}{*}{ Tar*Post*RD } & $0.0224^{* *}$ & $0.0233^{* *}$ & 0.00668 & 0.0716 \\
\hline & $(0.00969)$ & $(0.00908)$ & $(0.0213)$ & $(0.0440)$ \\
\hline Observations & 467,187 & 467,187 & 50,481 & 50,481 \\
\hline R-squared & 0.227 & 0.227 & 0.437 & 0.437 \\
\hline \multicolumn{5}{|l|}{ H3 } \\
\hline \multirow[t]{2}{*}{ Tar*Post*EI } & $-0.00759^{*}$ & $-0.00991^{*}$ & 0.00225 & 0.0125 \\
\hline & $(0.00405)$ & $(0.00598)$ & $(0.0135)$ & $(0.0233)$ \\
\hline Observations & 84,055 & 84,055 & 12,108 & 12,108 \\
\hline R-squared & 0.253 & 0.253 & 0.539 & 0.539 \\
\hline
\end{tabular}

Note: $* * *, * *$ and $*$ represent significance at the level of $1 \%, 5 \%$ and $10 \%$, respectively. Standard error is in brackets. All models include city-industry, city-year and industry-year fixed effects. To save space, the estimates of the intercept terms for each model are not reported. 


\subsection{HMT firms vs other foreign firms}

A large proportion of China's FDI is sourced from Hong Kong, Macao and Taiwan (HMT). It is argued that HMT firms may be attracted to the mainland by loose environmental regulations (Dean et al., 2008; Bu et al., 2013). As HMT firms have more historical and cultural ties with mainland China, so it is easy for them to get around environmental regulations. However, other FDI firms mainly from developed economies are more inclined to implement high environmental regulation standards adopted in their own countries. Thus these FDI firms are willing and able to adopt environmentally friendly technologies and strictly abide by environmental regulations because of the high legal and moral risks and the need to maintain their corporate image. For this reason, it is necessary to analyze HMT-funded firms and other FDI firms separately. The results are reported in Table 7.

Table 7 shows that emission reduction targeting has no significant impact on the output of "other FDI firms" but affects the output of HMT firms negatively (thus H1 is only confirmed for the HMT group only). The test results of $\mathrm{H} 2$ show that the strict environmental regulations have a significant promotion effect on the structural upgrading of HMT firms, while other FDI firms demonstrate hardly any impact from emission reduction targeting. In general, HMT FDI firms have invested less in environmental management than other FDI firms. Thus the testing results illustrate the catch-up effect on HMT firms and emission reduction targeting contributes to the overall industry upgrading which is much needed in China. The results in Table 7 however show no obvious difference between HMT firms and the other group. For both groups, it is found that emission reduction targeting affects the location choice of new FDI in China. Therefore $\mathrm{H} 3$ is once again confirmed. Under the pressure of increasing cost, FDI firms with high pollution intensity are more inclined to choose cities with lower emission reduction targets.

\section{Concluding remarks}

Emission reduction targeting adopted by China's central government since 2006 has 
had a profound impact on environmental protection and economic activities. As an important part of China's economy, FDI firms are bound to be affected by this environmental regulatory policy. Using a unique dataset of emission reduction targets of main pollutants ( $\mathrm{SO}_{2}$ and $\mathrm{COD}$ ) in 230 prefecture-level cities and micro database of FDI firms, this study empirically examines the impact of emission reduction targeting on FDI firms by using the DDD method. The estimation results demonstrate that stringent environmental regulations have a negative impact on the output of FDI firms, and particularly a greater effect on the output of those in pollution-intensive industries in cities with high emission reduction targets.

Table 7 HMT firms vs other foreign firms

\begin{tabular}{ccccc}
\hline & \multicolumn{2}{c}{ HMT firms } & \multicolumn{2}{c}{ Other FDI firms } \\
\hline $\boldsymbol{H} 1$ & $\mathrm{SO} 2$ & $\mathrm{COD}$ & $\mathrm{SO} 2$ & COD \\
Tar*Post*EI & $-0.00725^{* *}$ & $-0.00924^{*}$ & -0.00313 & -0.00796 \\
& $(0.00346)$ & $(0.00497)$ & $(0.00497)$ & $(0.00687)$ \\
Observations & 263,534 & 263,534 & 253,472 & 253,472 \\
R-squared & 0.269 & 0.269 & 0.273 & 0.273 \\
\hline $\boldsymbol{H} 2$ & & & & \\
Tar*Post*RD & $0.0274^{* *}$ & $0.0370^{* * *}$ & 0.00362 & $0.0134^{*}$ \\
& $(0.0109)$ & $(0.00975)$ & $(0.0146)$ & $(0.00790)$ \\
Observations & 263,534 & 263,534 & 253,472 & 253,472 \\
R-squared & 0.269 & 0.269 & 0.273 & 0.273 \\
\hline $\boldsymbol{H} 3$ & & & & \\
Tar*Post*EI & $-0.00797^{* *}$ & $-0.00665^{* *}$ & $-0.00916^{*}$ & $-0.0143^{* * *}$ \\
& $(0.00295)$ & $(0.00226)$ & $(0.00440)$ & $(0.00392)$ \\
Observations & 45,471 & 45,471 & 49,782 & 49,782 \\
R-squared & 0.340 & 0.340 & 0.318 & 0.318 \\
\hline
\end{tabular}

Note: $* * *, * *$ and $*$ represent significance at the level of $1 \%, 5 \%$ and $10 \%$, respectively. Standard error is in brackets. All models include city-industry, city-year and industry-year fixed effects. To save space, the estimates of the intercept terms for each model are not reported.

The findings in this paper also show that stringent environmental regulations may change the location distribution of FDI in China, which provides empirical evidence in support of the pollution heaven hypothesis internally within a large country. The consequence is that pollution-intensive new FDI firms tend to flow into cities with less pressure for emission reduction. Furthermore it is shown that stringent environmental regulations can help optimize the industrial structure of FDI in China. The output of hi- 
tech intensive industries may increase under the pressures of emission reduction targeting and high-tech intensive firms are also encouraged to enter more developed cities with greater pressure to reduce emission. In summary, stringent environmental regulations show mixed effects on FDI. On the one hand, it drives the migration of pollution-intensive FDI firms to cities with less pressure to reduce emissions. On the other hand, it also offers economically developed cities under greater pressure of emission reduction the opportunity to optimise FDI structure and hence promote industry upgrading in the local economies.

\section{References}

Arrow, K., Bolin, B., Costanza, R. (1996). Economic growth, carrying capacity and the environment. Ecological Applications. 6(1):13-15.

Berrone, P., Fosfuri, A., Gelabert, L., Gomez-Mejia, L. R. (2013). Necessity as the mother of "green" inventions: institutional pressures and environmental innovations. Strategic Management. 34(8):891-909.

Blalock, G., Gertler, J.P. (2008). Welfare gains from Foreign Direct Investment through technology transfer to local suppliers. Journal of international Economics, 74(2), 402-421.

Brandt, L., Van, B. J., Zhang, Y. (2012). Creative accounting or creative destruction? Firm-level productivity growth in Chinese manufacturing. Journal of Development Economic. 97(2):339351.

Bu, M.L., Liu, Z. B., Wagner, M., Yu, X.H. (2013). Corporate social responsibility and the pollution haven hypothesis: evidence from multinationals' investment decision in China. Asia-Pacific Journal of Accounting \& Economics. 20(1):85-99.

Cai, X., Lu, Y., Wu, M., Yu, L. (2016). Does environmental regulation drive away inbound foreign direct investment? Evidence from a quasi-natural experiment in China. Journal of Development Economics. 123:73-85.

Chen, Z., Matthew, E. K., Liu, Y., and Wang, Z. (2018). The consequences of spatially differentiated water pollution regulation in China. Journal of Environmental Economics and Management. 88(03): 468-485.

Chen, Z., Poncet, S., Xiong, R. (2017). Inter-industry relatedness and industrial-policy efficiency: evidence from China's export processing zones. Journal of Comparative Economics. 45(4):809-826.

Chung, S. 2014. Environmental regulation and foreign direct investment: evidence from South Korea. Journal of Development Ecnomics. 108:222-236.

Cole, M.A., Elliott, R.J.R., Zhang, J. (2011). Growth, foreign direct investment, and the environment: Evidence from Chinese cities. Journal Reginal. Science. 51, 121-138.

Cole, M.A., Elliott, R.J.R., Zhang, L.Y. (2017). Foreign Direct Investment and the Environment. Annual Review of Environment and Resources. 42:465-487.

Cole, M. A., Fredriksson, P. G. (2009). Institutionalized pollution havens. Ecological Economics. 68(4):1239-1256. 
Dean, J.M., Lovely, M.E., Wang, H., (2009). Are foreign investors attracted to weak environmental regulations? Evaluating the evidence from China. Journal of Development Economics, 90 (1), $1-13$.

Dechezleprêtre, D., Sato, M. (2017). The impacts of environmental regulations on competitiveness. Review of Environmental Economics and Policy. 11(2):183-206.

Deng, Y. P., Wu, Y.R., Xu, H.L. (2021). On the relationship between pollution reduction and export product quality: Evidence from Chinese firms. Journal of Environmental Management, 281, 111883.

Dijkstra, B. R., Mathew, A. J., Mukherjee, A. (2011). Environmental regulation: an incentive for foreign direct investment. Review of International Economics. 19(3):568-78.

Domazlicky, B. R., Weber, W. L. (2004). Does environmental protection lead to slower productivity growth in the chemical industry? Environmental \& Resource Economics. 28 (3):301-324.

Duviver, C., Xiong, H. (2013). Transboundary pollution in China: a study of polluting firms' location choices in Hebei province. Environment and Development Economics. 18(4):459-483.

Eskeland, G. S., Harrison, A. E. (2003). Moving to greener pastures? Multinationals and the pollution haven hypothesis. Journal of Development Economics. 70(1):1-23.

Fang, J. Y., Liu, C. J., Gao, C. (2019). The impact of environmental regulation on firm exports: evidence from environmental information disclosure policy in China. 26:37101-37113.

Fare, R., Grosskopf, S., CA, Pasurka, Jr. (2013). Tradable permits and unrealized gains from trade. Energy Economics. 40:416-424.

Greenstone, M. (2002). The impacts of environmental regulations on industrial activity: evidence from the 1970 and 1977 Clean Air Act amendments and the census of manufactures. Journal of Political Economics. 110(6):1175-1219.

Gunby, P., Jin, Y., Robert Reed, W. (2017). Did FDI really cause Chinese economic growth? A metaanalysis. World Development, 90, 242-255.

He, G. J., Fan, M. Y., Zhou, M. G. (2016). The effect of air pollution on mortality in China: Evidence from the 2008 Beijing Olympic Games. Journal of Environmental Economics and Management. 79:18-39.

Huang, J., Chen, X., Huang, B., Yang, X. (2017). Economic and environmental impacts of foreign direct investment in China: A spatial spillover analysis. China Economic. Review. 45:289-309.

Imbens, G. W., Wooldridge, J. M. (2007). What's new in econometrics? Lecture 10: difference-indifferences estimation. NBER Summer Institute.

Jeppesen, T., List, J. A., Folmer, H. (2002). Environmental regulations and new plant location decisions: evidence from a meta-analysis. Journal of regional science. 42(1):19-49.

Jia, R., Kudamatsu, M., Seim, D. (2015). Political selection in China: the complementary roles of connections and performance. Journal of the European Economic Association. 13(4): 631-668.

Kahn, M., Li, P., Zhao, D. (2015). Water pollution progress at borders: the role of changes in China's political promotion incentives. American Economic Journal: Economic Policy. 74 (4):223-242.

Keller, W., Levinson, A. (2002). Pollution abatement costs and foreign direct investment inflows to US states. Review Economic Statistics. 84(4):691-703.Kemp, R., Pontoglio, S. (2011). The innovation effects of environmental policy instruments: a typical case of the blind men and the elephant. Ecological Economics. 72(1725):28-36.

Kemp, R., Pontoglio, S. (2011). The innovation effects of environmental policy instruments - A typical case of the blind men and the elephant? Ecological Economics. 72(9):28-36. 
Ken, D. (2013). China Investment Policy: An update. OECD working papers on International Investment.

Levinson, A. (2010). Offshoring pollution: is the United States increasingly importing polluting goods? Review of Environmental Economics and Policy. 4 (1): 63-83.

Lin, L. G., Sun, W. (2016). Location choice of FDI firms and environmental regulation reforms in China. Journal of Regulatory Economics. 50(2):207-232.

List, J. A., McHone, W. W., Millimet, D. L. (2004). Effects of environmental regulation on foreign and domestic plant births: Is there a home field advantage? Journal of Urban Economics. 56(2):303-326.

Marshall, C. (1998). Economic instruments and the business use of energy. London: Report to Chancellor of the Exchequer.

MEP, 2006. The Guidelines for the Allocation of the Total Emissions of the Major Water Pollutants. Ministry of Environmental Protection, Beijing, China.

Millimet, D. L., Roy, J. (2016). Empirical tests of the Pollution Haven Hypothesis when environmental regulation is endogenous. Journal of Applied Econometrics. 31(4): 652-677.

Olden, A., Møen, J. (2020). The triple difference estimator. Discussion Paper. Department of Business and Management, NHH Norwegian School of Economics.

Qi, Y. (2013). Annual review of low-carbon development in China (2013) -Policy implication and institutional innovation. Tsinghua University and Climate Policy Initiative.

Salike, N. (2016). Role of human capital on regional distribution of FDI in China: New evidences. China Economic Review, 37, 66-84.

Shi, X.Z., Xu, Z.F. (2018). Environmental regulation and firm Exports: evidence from the Eleventh Five-Year Plan in China. Journal of Environmental Economics and Management, 89:187-200.

Tang, J. (2015). Testing the pollution haven effect: Does the type of FDI matter? Environmental and Resource Economics. 60(4):549-78.

Taylor, M. S. (2005). Unbundling the pollution haven hypothesis. Advances in Economic Analysis \& Policy, 3(2):1-26.

Wang, J., Zhao, T., Zhang, X. (2016). Environmental Assessment and Investment Strategies of Provincial Industrial Sector in China—Analysis Based on DEA Model. Environmental Impact Assessment Review. 60(9):156-168.

Wang, Y., Shen, N. (2016). Environmental Regulation and Environmental Productivity: The Case of China. Renewable and Sustainable Energy Reviews. 62: 758-766.

Wu, H., Guo, H., Zhang, B., Bu, M. (2017). Westward movement of new polluting firms in China: pollution reduction mandates and location choice. Journal of Comparative Economics. 45:119138.

Yang, D.L. (2017). China's illiberal regulatory state in comparative perspective. Chinese Political Science Review. 2(1):114-133.

Zeng, K., Eastin, J. 2012. Do developing countries invest up? The environmental effects of foreign direct investment from less-developed countries. World Development. 40(11):2221-2233.

Zhang, L. (2017). The knowledge spillover effects of FDI on the productivity and efficiency of research activities in China. China Economic Review, 42, 1-14.

Zhou. Y., Zhu. S. J., He, C. F. (2017). How do environmental regulations affect industrial dynamics? Evidence from China's pollution-intensive industries. Habitat International. 60:10-18. 


\section{Appendix}

Table A1 Summary statistics of the main variables.

\begin{tabular}{|c|c|c|c|c|c|}
\hline Variable & Description & Mean & S.D. & Max & Min \\
\hline \multicolumn{6}{|c|}{$\underline{\text { Firm-level }}$} \\
\hline FDI & Gross output of a FDI firm (thousands RMB) & 10.73 & 1.36 & 19.18 & 0 \\
\hline NFDI & $\begin{array}{l}\text { The amount foreign capital of a new firm } \\
\text { (thousands RMB) }\end{array}$ & 10.29 & 1.25 & 17.83 & 1.38 \\
\hline \multicolumn{6}{|c|}{ City-level } \\
\hline TarSO2 & $\mathrm{SO} 2$ reduction target $(\%)$ & 5.50 & 9.33 & 79.27 & 0 \\
\hline TarCOD & COD reduction target $(\%)$ & 5.06 & 8.13 & 103.00 & 0 \\
\hline GER & $\begin{array}{l}\text { Frequency of environment-related words in } \\
\text { Report on the Work of the Government (\%oo) }\end{array}$ & 0.43 & 0.14 & 1.09 & 0.10 \\
\hline \multicolumn{6}{|c|}{ Industry-level } \\
\hline EISO2 & $\begin{array}{l}\text { SO2 emission intensity at industry level } \\
(\mathrm{kg} / 10,000 \mathrm{RMB})\end{array}$ & 3.64 & 1.63 & 6.97 & 0.81 \\
\hline EICOD & $\begin{array}{l}\text { SO2 emission intensity at industry level } \\
(\mathrm{kg} / 10,000 \mathrm{RMB})\end{array}$ & 3.85 & 1.60 & 8.29 & 1.86 \\
\hline $\mathrm{RD}$ & R\&D intensity at industry level (\%) & 0.67 & 0.47 & 1.52 & 0.16 \\
\hline
\end{tabular}

Note: All variables appear in the models in logarithmic form (where there are zero values, a value of 1 is added to the variable). 